Saudi Journal of Medical and Pharmaceutical Sciences

Abbreviated Key Title: Saudi J Med Pharm Sci

ISSN 2413-4929 (Print) |ISSN 2413-4910 (Online)

Scholars Middle East Publishers, Dubai, United Arab Emirates

Journal homepage: http://scholarsmepub.com/sjmps/

Original Research Article

\title{
Evaluation of Antihyperglycemic and Antioxidant Activity of Fruits, Stems, and Leaves of Zanthoxylum Budrunga
}

\author{
Md. Mahbubur Rahman Bhuiyan ${ }^{1}$, Ummey Jannatun Nahar ${ }^{2 *}$, Anawara Begum ${ }^{3}$, Mohammed Rahmatullah ${ }^{1}$ \\ ${ }^{1}$ Department of Pharmacy, University of Development Alternative, 4/4, Block a, Lalmatia, Dhaka-1207, Bangladesh \\ ${ }^{2}$ Department of Pharmacy, Jagannath University, 9-10, Chittaranjan Ave, Dhaka-1100, Bangladesh \\ ${ }^{3}$ Department of Pharmacy, Stamford University Bangladesh, 51, Siddeswari Road, Dhaka-1217, Bangladesh
}

\begin{abstract}
DOI: $10.36348 /$ sjmps.2019.v05i12.007
| Received: 05.12.2019 | Accepted: 15.12.2019| Published: 18.12.2019

*Corresponding author: Ummey Jannatun Nahar
\end{abstract}

Abstract

Zanthoxylum budrunga is a tree worthy of investigation due to its many reported phytoconstituents and properties of rich medicinal value. A comprehensive study on the fruits, stems, and leaves of $Z$. budrunga was carried out to find out and assess the blood glucose lowering capacity as well as antioxidant potential. In vivo Oral Glucose Tolerance Test (OGTT) and in vitro 2, 2-diphenyl-1-picrylhydrazyl (DPPH) scavenging methods were applied to assess the hypoglycemic and antioxidant potentials of the plant extracts. Methanolic extract of $Z$. budrunga fruits (MZBF), methanolic extract of $Z$. budrunga stems (MZBS), and methanolic extract of $Z$. budrunga leaves (MZBL) showed graded dose-response relationship in OGTT. Most potent blood sugar level reduction was at the highest dose of $400 \mathrm{mg} / \mathrm{kg}$ body weight with the values of $44.26 \%$, 39.61\%, and 36.98\% for MZBF, MZBS, and MZBL respectively. Also MZBF, MZBS, and MZBL showed synergistic action with Glibenclamide with the value of 50.34, 43.02, and $45.11 \%$ blood glucose reduction, respectively. Comparative order of antioxidant activity was as fruits $\left(\mathrm{IC}_{50} 30.6 \mathrm{ppm}\right)>$ leaves $\left(\mathrm{IC}_{50} 68.38 \mathrm{ppm}\right)>$ stems $\left(\mathrm{IC}_{50} 126.83 \mathrm{ppm}\right)$ where ascorbic acid $\left(\mathrm{IC}_{50} 0.17 \mathrm{ppm}\right)$ was used as standard. The results indicate that Z. budrunga fruits, stems, and leaves have the potential to be used in hyperglycemic condition as folk medicine. Besides these, fruits and leaves may be used as functional food and preventive medicine for oxidative stress disorders like aging-induced disorders, neurodegenerative diseases, liver diseases, cancer etc.

Keywords: Zanthoxylum budrunga, Zanthoxylum rhetsa, DPPH, hypoglycemic, antioxidant, diabetes.

Copyright @ 2019: This is an open-access article distributed under the terms of the Creative Commons Attribution license which permits unrestricted use, distribution, and reproduction in any medium for non-commercial use (NonCommercial, or CC-BY-NC) provided the original author and source are credited.

\section{INTRODUCTION}

Zanthoxylum genus is a member of Rutaceae family (Subfamily: Rutoideae) [1]. Zanthoxylum budrunga (Synonym: Zanthoxylum rhetsa) is a deciduous, medium-sized tree with plain and cork-like bark [2], which is indigenous to the hot temperate and subtropical regions. This plant is extensively grown in Bangladesh (known as "Bajna") and in the neighboring countries like India, Myanmar, Nepal and some other countries like Thailand, China, Malaysia, Philippines, Indonesia, and Papua New Guinea [3]. Different parts of this plant are used for many problems of heart, lungs, GIT, teeth, mouth, throat etc. [3, 4]. Fruits are beneficial for cholera, dysentery, bronchitis, asthma, infections, heart disease, rheumatism, and piles while stem bark is effective against nociception and diarrhea. Leaves also are used in cholera [3-5]. Phytochemicals isolated and identified from this plant include alkaloids obtained from the bark of Z. budrunga, namely $\mathrm{N}$ methylflindersine, zanthobungeanine, dictamine, skimmianine [1]. Presence of another five compounds lupeol, dihydrochelerythrine, N-norchelerythrine, ( \pm )evodiamine, and zanthobungeanine in the root bark of $Z$. Budrunga was confirmed by Nuclear magnetic resonance (NMR) study [6]. Moreover, alkaloids pseudophrynamine, lunacridine, and 2-(2', 4', 6'trimethyl-heptenyl)-4-quinozolone were separated from leaves [3]. Leaves of $Z$. budrunga also possess 5methoxy-7-hydroxy flavonone [4]. Furthermore, fruits comprise alkaloids like glycosine, rutaecarpine and volatile components like hydroxy $\alpha$-sanshool, $\beta$ phellandrene, $\beta$-pinene, pipertone, and mullilamdiol. Trihydroxy- $p$-menthane has been isolated from roots of Z. budrunga [3].

Rathnayaka et al. reported about the $\alpha$-amylase inhibitory activity of bark of $Z$. budrunga, which is indicative for use of this bark in the treatment of type-2 diabetes mellitus to reduce postprandial hyperglycemia $[7,8]$, but there is no comprehensive study to report on the hypoglycemic or antidiabetic effect of various plant parts of Z. budrunga. However, diabetes is a chronic 
ailment and is reaching nearly endemic proportions in Bangladesh. Since Bangladesh still lags to provide affordable medications to both the people of the rural and remote parts of the country, a readily available and affordable source of anti-diabetic agent is desperately needed. With a view to resolving this problem the study was designed to evaluate the antihyperglycemic activity of fruits, stems, and leaves of $Z$. budrunga alongside the antioxidant activity of specific parts of the plant.

\section{MATERIALS AND METHODS \\ Extraction of plant parts}

Fruits, stems, and leaves of Zanthoxylum budrunga were collected from Manipur, Gazipur district in Bangladesh during the months of September and October 2017. The plant parts were identified at the Bangladesh National Herbarium (ACCN No. fruitsDACB 46094 and stems, leaves- DACB 45389) and sample specimens were deposited there.

All plant parts were washed after collection and then dried in the shade, which was followed by grinding. The powder of fruits, stems, and leaves was soaked separately in $100 \%$ methanol for 8 days with occasional stirring. After drying of the three different filtrates, about 5\%, 1.1\%, and $1.6 \%(\mathrm{w} / \mathrm{w})$ crude extracts of fruits, stems, and leaves were obtained, respectively.

\begin{abstract}
Animals
Swiss albino mice of 20-25 g were employed in the experiment of in vivo hypoglycemic effect evaluation. Seven days prior the experiment the mice were purchased from ICDDR,B (International Centre for Diarrhoeal Disease Research, Bangladesh) and kept in the laboratory (temperature $25 \pm 2^{\circ} \mathrm{C}$ and humidity 55$60 \%$ ) on 12 hrs dark-light cycle for acclimatization with the experimental environment. Standard food provided by ICDDR, B along with plentiful fresh water was provided ad libitum. For $12 \mathrm{hrs}$ the mice were kept on fasting before the experiment and only fresh water was allowed to take up to the experiment day. The study was performed following approval by the Institutional Animal Ethical Committee of University of Development Alternative, Dhaka, Bangladesh.
\end{abstract}

\section{Chemicals}

Reagent grade methanol (Merck, Germany), dimethyl sulfoxide (Merck, Germany), and 2, 2diphenyl-1-picrylhydrazyl were used. Glucose and Glibenclamide were obtained from Square Pharmaceuticals, Bangladesh.

\section{Hypoglycemic effect evaluation by Oral Glucose Tolerance Test (OGTT)}

Fourteen (14) groups consisting of 5 numbers of mice in each group $(\mathrm{Gr})$ were used for the entire experiment. Control group or Group 1 was orally administered $10 \mathrm{ml} / \mathrm{kg}$ diluents, and standard group or Group 2 was orally administered $10 \mathrm{mg} / \mathrm{kg}$ Glibenclamide. Groups 3-6 were given 100mg, 200mg, $400 \mathrm{mg}$ methanolic extract Z. budrunga fruits (MZBF) per $\mathrm{kg}$ body weight and 400mg MZBF along with $10 \mathrm{mg} / \mathrm{kg}$ Glibenclamide, respectively. In the same order, Gr-7 to Gr-10 were treated with methanolic extract of Z. budrungastems (MZBS), while Gr-11 to Gr-14 were administered methanolic extract of $Z$. budrunga leaves (MZBL). All treatments were done orally. After one hour of oral gavage of all groups, $2 \mathrm{~g}$ glucose $/ \mathrm{kg}$ was administered to each group. Blood sugar level was measured after 120 minutes of oral gavage of glucose by glucometer, which works based on the principle of glucose oxidation method. Blood sugar lowering in percent was calculated by using the formula stated below [9]. Percent lowering of blood glucose level $=(1-\mathrm{We} / \mathrm{Wc}) \times 100$.

Where we and Wc represent the blood glucose concentration in Glibenclamide or extracts (MZBF, MZBS, MZBL) administered mice (Groups 2-14) and control mice (Group 1) respectively.

\section{Antioxidant potential determination by DPPH scavenging method}

DPPH radical scavenging capacity was based on the method as previously described with minor modifications [10]. In this study different concentrations, $0.1543 \mathrm{ppm}$ to $1.563 \mathrm{ppm}$ for ascorbic acid (used as standard) and $400 \mathrm{ppm}$ to $1.563 \mathrm{ppm}$ for each extract (MZBF, MZBS, and MZBL) were used. The formula used for calculation of percent inhibition of the free radical is given below. \% Inhibition = (Absorbance of blank - Absorbance of Test sample) $\mathrm{x}$ 100/ Absorbance of blank

\section{STATISTICAL ANALYSIS}

Statistical analysis of the hypoglycemic study was performed by one way ANOVA followed by Dunnett's post hoc test with SPSS software (version 20). Data analysis of the antioxidant study was accomplished by Microsoft Excel 2013.

\section{RESULTS \\ Hypoglycemic effect}

For each extract's evaluation, Gr-1 and Gr-2 were common. There was a dose-dependent increment of the blood glucose level reduction capability of MZBF, MZBS, and MZBL. All values of blood glucose level $(\mathrm{mmol} / \mathrm{L})$ and percent reduction of blood glucose level are considered as statistically significant at $\mathrm{P}<0.001$ when compared with control. Effects of the methanolic extract of $Z$. budrunga fruits, stems and leaves on blood glucose lowering are shown in Table 1. 
Mahbubur Rahman Bhuiyan et al; Saudi J Med Pharm Sci, Dec., 2019; 5(12): 1054-1058

Table-1: Effect of methanolic extracts of Z. budrunga fruits, stems and leaves on blood glucose lowering

\begin{tabular}{|c|c|c|c|c|}
\hline & Group & Dose & $\begin{array}{l}\text { Blood glucose } \\
\text { level }(\mathrm{mmol} / \mathrm{L})\end{array}$ & $\begin{array}{c}\% \text { reduction of blood } \\
\text { glucose level }\end{array}$ \\
\hline & Gr-1 (Control ) & $10 \mathrm{ml}$ & $6.46 \pm 0.09$ & -- \\
\hline & $\begin{array}{c}\text { Gr-2 } \\
\text { (Glibenclamide) }\end{array}$ & $10 \mathrm{mg} / \mathrm{kg}$ & $3.56^{*} \pm 0.16$ & $44.85^{*}$ \\
\hline \multirow{4}{*}{ Fruits } & Gr-3 (MZBF) & $100 \mathrm{mg} / \mathrm{kg}$ & $4.42^{*} \pm 0.07$ & $31.58^{*}$ \\
\hline & Gr-4 (MZBF) & $200 \mathrm{mg} / \mathrm{kg}$ & $4.06^{*} \pm 0.11$ & $37.07^{*}$ \\
\hline & Gr-5 (MZBF) & $400 \mathrm{mg} / \mathrm{kg}$ & $3.6^{*} \pm 0.07$ & $44.26^{*}$ \\
\hline & $\begin{array}{l}\text { Gr-6 (MZBF + } \\
\text { Glibenclamide ) }\end{array}$ & $400 \mathrm{mg} / \mathrm{kg}+10 \mathrm{mg} / \mathrm{kg}$ & $3.2^{*} \pm 0.13$ & $50.34^{*}$ \\
\hline \multirow{4}{*}{ Stems } & Gr-7 (MZBS) & $100 \mathrm{mg} / \mathrm{kg}$ & $5.4^{*} \pm 0.25$ & $16.23^{*}$ \\
\hline & Gr-8 (MZBS) & $200 \mathrm{mg} / \mathrm{kg}$ & $4.5^{*} \pm 0.13$ & $30.29^{*}$ \\
\hline & Gr-9 (MZBS) & $400 \mathrm{mg} / \mathrm{kg}$ & $3.9^{*} \pm 0.19$ & $39.61^{*}$ \\
\hline & $\begin{array}{l}\text { Gr-10 (MZBS + } \\
\text { Glibenclamide ) }\end{array}$ & $400 \mathrm{mg} / \mathrm{kg}+10 \mathrm{mg} / \mathrm{kg}$ & $3.68^{*} \pm 0.05$ & $43.02^{*}$ \\
\hline \multirow{4}{*}{ Leaves } & Gr-11 (MZBL) & $100 \mathrm{mg} / \mathrm{kg}$ & $5.4^{*} \pm 0.12$ & $16.38^{*}$ \\
\hline & Gr-12 (MZBL) & $200 \mathrm{mg} / \mathrm{kg}$ & $4.74^{*} \pm 0.11$ & $26.59^{*}$ \\
\hline & Gr-13 (MZBL) & $400 \mathrm{mg} / \mathrm{kg}$ & $4.06^{*} \pm 0.22$ & $36.98^{*}$ \\
\hline & $\begin{array}{l}\text { Gr-14 (MZBL + } \\
\text { Glibenclamide ) }\end{array}$ & $400 \mathrm{mg} / \mathrm{kg}+10 \mathrm{mg} / \mathrm{kg}$ & $3.54^{*} \pm 0.07$ & $45.11^{*}$ \\
\hline
\end{tabular}

All treatments were given by oral gavage. Values of blood glucose level are presented as mean blood glucose level \pm SEM and Values of \% reduction of blood glucose level are presented as mean \% reduction of blood glucose level; indicates $\mathrm{P}<0.001$; statistically significant compared to hyperglycemic control animals.

At the highest dose $(400 \mathrm{mg} / \mathrm{kg}$ body wt.) each extract showed more than $35 \%$ blood glucose level reduction. Highest value $(44.26 \%)$ of blood glucose level reduction was recorded for MZBF at $400 \mathrm{mg} / \mathrm{kg}$ which was comparable to that $(44.85 \%)$ shown by the standard drug at $10 \mathrm{mg} / \mathrm{kg}$ body wt. Synergistic effect upon the administration of extracts in combination with
Glibenclamide was also shown by MZBF, MZBS, and MZBL. MZBF exhibited most potent synergistic effect with a value of $50.34 \%$ reduction of blood glucose level in combination with Glibenclamide among all three crude extracts.

\section{Antioxidant potential}

To assess the antioxidant potential of plant extract $\mathrm{IC}_{50}$ value is indicative. Ascorbic acid (standard) showed $\mathrm{IC}_{50}$ value $0.17 \mathrm{ppm}$. MZBF showed the highest antioxidant property with $\mathrm{IC}_{50}$ value $30.6 \mathrm{ppm}$, while $\mathrm{IC}_{50}$ value $126.83 \mathrm{ppm}$ was exhibited by MZBS making it least potential extract for antioxidant activity. Values of $\mathrm{IC}_{50}$ for $Z$. budrunga fruits, stems, and leaves obtained from DPPH method are given in Table 2.

Table-2: Percent inhibition and IC50 values of $Z$. budrunga fruits, stems, and leaves by DPPH method

\begin{tabular}{|c|c|c|c|c|c|c|c|c|c|}
\hline \multirow[b]{2}{*}{$\begin{array}{l}\text { Conc. } \\
\text { (ppm) }\end{array}$} & \multicolumn{2}{|c|}{ Ascorbic Acid } & \multirow{2}{*}{$\begin{array}{l}\text { Conc. } \\
\text { (ppm) }\end{array}$} & \multicolumn{2}{|c|}{ Fruits } & \multicolumn{2}{|c|}{ Stems } & \multicolumn{2}{|c|}{ Leaves } \\
\hline & $\begin{array}{c}\% \\
\text { Inhibition }\end{array}$ & $\begin{array}{c}\mathrm{IC}_{50} \\
\text { Value } \\
(\mathrm{ppm}) \\
\end{array}$ & & $\begin{array}{c}\% \\
\text { Inhibition }\end{array}$ & $\begin{array}{c}\mathrm{IC}_{50} \\
\text { Value } \\
(\mathrm{ppm}) \\
\end{array}$ & $\begin{array}{c}\% \\
\text { Inhibition }\end{array}$ & $\begin{array}{c}\mathrm{IC}_{50} \\
\text { Value } \\
(\mathrm{ppm}) \\
\end{array}$ & $\begin{array}{c}\% \\
\text { Inhibition }\end{array}$ & $\begin{array}{c}\mathrm{IC}_{50} \\
\text { Value } \\
(\mathrm{ppm})\end{array}$ \\
\hline 0.0067 & 98.046 & \multirow{9}{*}{0.17} & 1.563 & 20.79 & \multirow{9}{*}{30.6} & 6.55 & \multirow{9}{*}{126.83} & 9.59 & \multirow{9}{*}{68.38} \\
\hline 0.0090 & 97.375 & & 3.125 & 34.29 & & 9.34 & & 13.10 & \\
\hline 0.0091 & 97.345 & & 6.25 & 40.77 & & 10.63 & & 11.31 & \\
\hline 0.0063 & 98.162 & & 12.5 & 59.63 & & 34.40 & & 44.06 & \\
\hline 0.0138 & 95.974 & & 25 & 65.75 & & 47.82 & & 60.59 & \\
\hline 0.0153 & 95.537 & & 50 & 83.64 & & 59.84 & & 71.80 & \\
\hline 0.0188 & 94.516 & & 100 & 91.27 & & 57.66 & & 89.98 & \\
\hline 0.0940 & 72.579 & & 200 & 95.74 & & 83.72 & & 89.44 & \\
\hline 0.1543 & 54.988 & & 400 & 95.53 & & 90.87 & & 96.06 & \\
\hline
\end{tabular}

\section{DISCUSSION}

OGTT is a simple, easy, and preliminary test to evaluate oral glucose tolerance and consequential elevated blood glucose level reduction capability of the sample in the glucose loaded animal. The result of this experiment shows the hypoglycemic action of the 
methanolic extracts of fruits, stems, and leaves of $Z$. budrunga and indicates the possibility of the presence of glucose-lowering component(s) in the extracts. The plant parts are reported to have flavones, alkaloids, saponins, terpene etc [5], one or more of which may be accountable to show the observed blood glucose lowering effects in mice [11]. Some plants can reduce postprandial glucose reduction by $\alpha$-glucosidase and $\alpha$ amylase inhibition which then delay the glucose absorption from gut wall thus giving more time to utilize the glucose by cells $[12,13]$. The other possible mechanisms to reduce the plasma glucose are insulinstimulated glucose utilization [14], insulin receptor activation [15], and increased peripheral glucose utilization, increasing the hepatic glycogen synthesis or decreasing glycogenolysis, reduction of glutathione effect and glycemic index of carbohydrate [16]. Any one or multiple mechanisms stated above may be responsible for the exhibition of hypoglycemic effect by fruits, stems, and leaves of the experimental plant; however, the exact mechanism needs to be elucidated. Medicinal plants have a great range of antioxidant system including enzymatic and non-enzymatic to mitigate the stress induced by Reactive oxygen species (ROS). Enzymatic system includes superoxide dismutase (SOD), peroxidases (POD), catalase (CAT), ascorbate peroxidase (APX), dehydroascorbate reductase (DHAR), monodehydroascorbate reductase (MDHAR), glutathione reductase (GR) etc. Antioxidants glutathione, ascorbate, carotenoids, thioredoxin, tocopherols are considered as the member of non-enzymatic [17]. It is likely that the antioxidant activity revealed by the $Z$. budrunga plant parts may apply any of these systems.

\section{CONCLUSION}

The results of this study of oral glucose tolerance test confirm the potent hypoglycemic activity of methanolic fruits, stems, and leaves extract of $Z$. budrunga. However, additional studies to investigate the antidiabetic effect and to specify the mechanism of action of this effect of the plant parts are needed. Results of DPPH scavenging property are indicative to have significant antioxidant bioactivities. This is important because oxidative stress can lead to diabetes [18]; on the other hand, diabetes itself can lead to high oxidative stress, which in turn can lead to complicated disorders like cardiovascular disorders, diabetic retinopathy, neuropathy and nephropathy [19]. This plant may be used as a medicinal plant to treat diabetes and for the prevention of cardiovascular diseases, stroke, cancer etc. through further specific studies. High-throughput screening of $Z$. budrunga may result in new antidiabetic and antioxidant agents.

\section{ACKNOWLEDGMENT}

Authors are thankful to Fatema Moni and Md. Najmul Hossain for kind assistance during the study period.

\section{CONFLICT OF INTEREST}

There is no conflict of interest to declare.

\section{REFERENCES}

1. Lin, A. E., Birch, P. H., Korf, B. R., Tenconi, R., Niimura, M., Poyhonen, M., ... \& Bonioli, E. (2000). Cardiovascular malformations and other cardiovascular abnormalities in neurofibromatosis 1. American journal of medical genetics,95(2), 108-117.

2. Mukhlesur Rahman, M., Anwarul Islam, M., Khondkar, P., \& Gray, A. I. (2005). Alkaloids and lignans from Zanthoxylum budrunga (Rutaceae). Biochemical systematics and ecology, 33(1), 91-96.

3. Islam, M., Biswas, N. N., Saha, S., Hossain, H., Jahan, I. A., Khan, T. A., ... \& Shilpi, J. A. (2014). Antinociceptive and antioxidant activity of Zanthoxylum budrunga Wall (Rutaceae) seeds. The Scientific World Journal, 2014.

4. Islam, A., Abu Sayeed, M., Islam, A. U., Khan, G. A. M., Biswas, M. H. U., \& Bhuiyan, M. S. A. (2001). A Flavonone from Leaves of Zanthoxylum budrunga: its In vitro Antimicrobial Activity and Cytotoxic Evaluation. Journal of Medical Sciences, 1(4), 209-213.

5. Bhadoriya, U. P. E. N. D. R. A., Yadav, A. K. A. S. H., Aggarwal, N. A. V. N. E. E. T., Jaiswal, D., Yadav, I. K., Singh, H. P., ... \& Jain, D. A. (2009). Hypnotic effect of essential oil and methanolic extract of fruits of zanthoxylum budrunga w. Int. J. Pharmtech. Res, 1(4), 1494-1498.

6. Joshi, B. S., Moore, K. M., Pelletier, S. W., \& Puar, M. S. (1991). Alkaloids of zanthoxylum budrunga wall.: NMR assignments of dihydrochelerythrine, $( \pm)$-evodiamine and zanthobungeanine. Phytochemical analysis, 2(1), 20-25.

7. Rathnayaka, G. R. N., Wickramaratne, M. N., Kumar, N. S., \& Jayasinghe, L. (2014). Bioactivity Screening of the Knotty Protuberances in the Bark of Zanthoxylum Budrunga.

8. Agarwal, P., \& Gupta, R. (2016). Alpha-amylase inhibition can treat diabetes mellitus. Res. Rev. J. Med. Health Sci, 5, 1-8.

9. Bhuiyan, M. M. R., Nahar, U. J., \& Begum, A. (2019). Evaluation of Hypoglycemic effect of extracts from Derris scandens and Thunbergia erecta leaves in Swiss albino mice. Research Journal of Pharmacy and Technology, 12(7), 34673470.

10. Brand-Williams, W., Cuvelier, M. E., \& Berset, C. L. W. T. (1995). Use of a free radical method to evaluate antioxidant activity. LWT-Food science and Technology, 28(1), 25-30.

11. Hasan, M. N., Rahman, M. H., Guo, R., \& Hirashima, A. (2015). Hypoglycemic activity of methanolic leaf extract of Blumea lacera in Swiss- 
albino mice. Asian Pacific Journal of Tropical Disease, 5(3), 195-198.

12. Archit, R., Gayathri, M., \& Punnagai, M. (2013). An in vitro investigation into the mechanism of anti-diabetic activity of selected medicinal plants. International Journal of Drug Development and Research, 9(2), 2.

13. Paulraj, J. A., Subharamanian, H., Suriyamoorthy, P., \& Kanakasabapathi, D. (2014). Phytochemical screening, gc-ms analysis and enzyme inhibitory activity of passiflora foetida L. Indo American Journal of Pharmaceutical Research, 4(8), 35263534.

14. Eid, H. M., \& Haddad, P. S. (2014). Mechanisms of action of indigenous antidiabetic plants from the boreal Forest of northeastern Canada. Advances in Endocrinology, 2014.
15. Joy, K. L., \& Kuttan, R. (1999). Anti-diabetic activity of Picrorrhiza kurroa extract. Journal of Ethnopharmacology, 67(2), 143-148.

16. Patel, D. K., Prasad, S. K., Kumar, R., \& Hemalatha, S. (2012). An overview on antidiabetic medicinal plants having insulin mimetic property. Asian Pacific journal of tropical biomedicine, 2(4), 320-330.

17. Puthur, J. T. (2016). Antioxidants and cellular antioxidation mechanism in plants. South Indian Journal of Biological Sciences, 2(1), 14-17.

18. Asmat, U., Abad, K., \& Ismail, K. (2016). Diabetes mellitus and oxidative stress-A concise review. Saudi Pharmacentical Journal, 24(5), 547553.

19. Kashiwagi, A. (2001). Complications of diabetes mellitus and oxidative stress. Japan Medical Association Journal, 44(12), 521-528. 